\title{
Makna Simbolik dalam Iklan Cerdas dan Target Perilaku Khalayak
}

\section{Symbolic Meanings in Smart Advertising and Target Audience Behavior}

\author{
Ferdinand Eskol Tiar Sirait*
}

\author{
Departemen Ilmu Komunikasi, Fakultas Ilmu Sosial dan Politik, Universitas Indonesia, \\ Indonesia \\ Diterima: 16 Agustus 2020; Disetujui: 14 Desember 2020; Dipublish: 31 Januari 2021
}

\begin{abstract}
Abstrak
Artikel ini bertujuan untuk membahas konsep smart advertising terutama berkaitan dengan tujuan dan efek dari smart smart advertising untuk membentuk top of mind khalayak. Penelitian ini dilakukan dengan penelitian kepustakaan (library research) dengan pendekatan analisis deskriptif, yaitu mengumpulkan data, menyusun atau mengklarifikasi, dan menginterpretasinya. Teknik yang digunakan dalam penelitian ini, yaitu dengan cara menganalisis kalimat-kalimat iklan, dilihat dari penggunaan interferensi. Data dalam penelitian ini diperoleh dari beberapa sumber yang di dalamnya terdapat interferensi. Kajian ini menyimpulkan bahwa Salah satu strategi yang banyak digunakan untuk meningkatkan nilai iklan adalah "smart advertising" atau iklan yang dilakukan dengan penargetan perilaku. Dengan menggunakan informasi tentang perilaku online, termasuk situs yang dikunjungi dan minat pada jenis konten tertentu, penargetan perilaku berupaya untuk menayangkan iklan yang lebih menarik bagi kelompok konsumen tertentu. Meskipun terdapat potensi peningkatan yang dramatis untuk pengiklan dan penerbit online, beberapa pengguna dan kelompok advokasi pengguna telah menyatakan keprihatinan atas masalah privasi yang ditimbulkan oleh penargetan perilaku Kata Kunci: Behavioral Targeting; Komunikasi Periklanan; Smart Advertising.
\end{abstract}

\section{Abstract}

This article aims to discuss the concept of smart advertising, especially with regard to the goals and effects of smart smart advertising to form the top of the mind of the audience. This research was conducted with library research (library research) with a descriptive analysis approach, namely collecting data, compiling or clarifying, and interpreting it. The technique used in this research, namely by analyzing advertisement sentences, seen from the use of interference. The data in this study were obtained from several sources in which there was interference. This study concludes that one of the most widely used strategies to increase the value of advertising is "smart advertising" or advertising that is carried out with behavioral targeting. By using information about online behavior, including sites visited and interest in certain types of content, behavior targeting seeks to serve ads that are more attractive to certain groups of consumers. Despite the potential for a dramatic increase for online advertisers and publishers, some users and user advocacy groups have expressed concern over the privacy concerns posed by behavioral targeting.

Keywords: Behavioral Targeting; Advertising Communication; Smart Advertising.

How to Cite: Sirait, F.E.T., (2021). Makna Simbolik dalam Iklan Cerdas dan Target perilaku Khalayak. PERSPEKTIF, 10 (1) 1:140-148.

$\begin{array}{lr}\text { *Corresponding author: } & \text { ISSN 2085-0328 (Print) } \\ \text { E-mail: ferdinand@upnvi.ac.id } & \text { ISSN2684-9035 (Online) }\end{array}$




\section{PENDAHULUAN}

Periklanan adalah industri yang melibatkan hubungan tiga arah antara pengiklan, agensi mereka, dan media. Sejarah industri ini berasal dari akhir abad kesembilan belas di negara-negara industri, sedangkan abad kedua puluh telah terlihat pertumbuhannya pada skala global. Visibilitas tinggi membuat iklan telah menarik banyak kritik sosial dan pendekatan analitik berturutturut selama ini, dengan perhatian yang berfokus pada peran iklan dalam pembentukan merek dan identitas sosial. Penghasilan iklan tidak hanya menyediakan sumber pendapatan utama bagi pemilik media cetak dan siaran, tetapi juga memberikan media tersebut tampilan dan suara khas mereka, dan mengarahkan konten mereka ke jenis audiens yang ingin dijangkau oleh pengiklan. Periklanan dapat didefinisikan sebagai semacam industri budaya yang menghubungkan produsen barang dan jasa konsumen dengan pasar potensial melalui difusi pesan pembayaran di media. Dalam industri, periklanan dipandang sebagai hanya satu bagian dari apa yang sekarang disebut 'komunikasi pemasaran terpadu'. Namun iklan dibedakan karena menjadi dimensi imajiner dari apa yang disebut kompleksitasnya antara manufaktur-pemasaran-mediadari masyarakat modern, seluruh struktur kelembagaan produksi dan konsumsi. Periklanan memiliki asal bukan hanya dalam penjualan ruang dan waktu, tetapi berperan memberikan identitas yang berbeda untuk barang dan layanan bermerek. Di AS dan Inggris muncul sekitar akhir abad ke-19 ketika produk-produk rumah tangga yang dikemas mulai menggantikan barang-barang generik yang dibeli dalam jumlah besar. Dengan memberikan karakter tertentu pada merek dan sering kali logo atau slogan untuk membuat mereka dikenali, iklan berkontribusi terhadap ekspansi merek nasional, dan kemudian internasional, seperti Lipton, Gillette, Kodak, dan Ford. Pada 1920-an, periklanan membentuk aliansi dengan apa yang pada waktu itu masih merupakan hal baru dalam ilmu sosial dengan menggunakan teknik sosiologis untuk riset pasar, dan menyusun daya tarik psikologis untuk iklan itu sendiri. (Sinclair, 2015). Sejarah periklanan sebagian besar adalah sejarah biro iklan yang telah melayani kebutuhan ketiga kelompok ini. Mereka menghubungkan industri dan media dengan membuat formulir baru untuk pesan tentang produk dan jasa; industri dan konsumen dengan mengembangkan kampanye komunikasi yang komprehensif dan memberikan informasi di atasnya; dan media dan konsumen dengan melakukan riset khalayak untuk memungkinkan segmentasi pasar (Moeran, 2015).

Iklan yang digunakan semakin berkembang dan beragam, baik dalam bentuk maupun medium yang digunakan seperti iklan bergambar, iklan media sosial, dan iklan dalam format medium digital lainnya. Dalam skenario bisnis yang berkembang, periklanan menjadi lebih efektif seiring berjalannya waktu. Dalam konteks produk baru, di mana manajer dan konsumen mungkin belajar tentang efektivitas periklanan dan aturan anggaran, efek dinamis dapat menjadi kuat dan meneruskan investasi periklanan. Oleh karena itu, dalam skenario bisnis yang berkembang, alokasi anggaran perlu memperhitungkan biaya iklan yang lalu, bahkan mungkin yang dilaksanakan beberapa bulan sebelumnya (Kireyev et al., 2016).

Sementara iklan dalam medium media sosial seperti facebook, twitter, instagram, dan lainnya juga berkembang dengan pesat seiiring dengan kemajuan teknologi dan komunikasi. Media sosial telah menjadi bagian dari kehidupan manusia. Media sosial memberdayakan pengguna untuk menyebar dan berbagi informasi secara instan dan luas. Media sosial memainkan peran yang semakin penting dalam kehidupan sehari-hari orang dan menarik perusahaan untuk melakukan kegiatan pemasaran. Menentukan cara bagaimana memanfaatkan media baru ini secara efektif untuk mendistribusikan iklan promosi kepada pelanggan yang sesuai merupakan masalah penting. Mekanisme penyebaran sosial berbasis endorser, yang mempertimbangkan faktor-faktor preferensi, pengaruh, dan kekuatan difusi pengguna, diusulkan untuk meningkatkan efektivitas iklan target dengan menemukan endorser yang paling tepat yang dapat menyebarkan iklan ke yang diidentifikasi sebagai target pengguna. Model yang diusulkan dapat secara tepat meningkatkan kepuasan dan tingkat pengiriman target (Lin et al., 2015).

Penggunaan iklan dalam platform media sosial yang semakin mudah dan gampang untuk diakses digunakan dalam berbagai industri termasuk digunakan oleh para olahragawan 
maupun sosialita. Misalnya dalam penggunaal pada platform twitter. Twitter memiliki dukungan untuk bermain di bidang pengesahan produk untuk atlet profesional dan bisnis sebagai pujian dan / atau suplemen untuk upaya offline. Sebagai media komunikasi yang dikendalikan sendiri, Twitter menyediakan platform bagi para atlet untuk mengembangkan merek mereka sendiri serta mempromosikan upaya pemasaran mereka. Dengan demikian, dengan menggunakan Twitter untuk potensinya, atlet mungkin dapat meningkatkan penghasilan mereka dari kesepakatan pengesahan serta kegiatan pemasaran lainnya. (Abeza et al., 2017).

Selanjutnya media periklanan berkembang dengan salah satunya adalah digital signage. Digital signage adalah teknologi komunikasi yang baru muncul. Diharapkan untuk memainkan peran penting dalam dunia yang dinamis saat ini karena signage digital menampilkan informasi yang tepat waktu, sekaligus mengurangi biaya lingkungan yang terkait dengan signage dicetak tradisional. Fokus utamanya adalah desain, implementasi, dan evaluasi sistem signage digital berbasis pada PC untuk menampilkan konten web (atau informasi dinamis lainnya) pada tampilan digital yang terletak di satu atau lebih lokasi. Sistem akan menampilkan informasi berdasarkan keinginan konten yang dapat diperbarui secara dinamis. Ini menghindari satu titik kegagalan sistem berbasis televisi (baik itu analog atau IPTV), karena setiap layar memiliki prosesor terpasang dan penyimpanan lokal yang berisi informasi yang akan ditampilkan dan daftar putar lokal tentang apa yang akan ditampilkan. Selain itu, desain memungkinkan konten untuk disesuaikan dengan pemirsa lokal tertentu misalnya informasi yang ditampilkan dapat disesuaikan dengan pengguna atau pengguna yang saat ini berada di depan layar. Pendekatan terhadap signage digital ini akan menggantikan sistem signage yang ada (Khan et al., 2014).Pasar untuk signage digital telah berkembang dengan kecepatan yang dipercepat selama bertahuntahun. Manfaat dari pendekatan baru - seperti kontekstualisasi dan fungsi interaksi - segera diakui untuk mencapai efek iklan yang lebih baik. Namun, tipe utama dari signage digital yang saat ini digunakan memiliki persyaratan yang berbeda pada keseluruhan sistem signage digital. Persyaratan ini mencakup komponen seperti jaringan signage digital, pertukaran signage digital, penjadwalan, dan harga. Kontribusi inti dari makalah ini adalah analisis rinci tentang potensi signage digital. Penekanan ditempatkan pada tantangan dalam pengukuran kinerja dan implementasi, mengoperasikan dan menggunakan sistem signage digital, kebutaan layar, dan eksternalitas negatif. Solusi yang mungkin, serta praktik terbaik disajikan. Pada intinya saat ini melakukan bisnis dengan signage digital adalah sebuah hal yang penting (Van Den Hooff, 2017).

Sebagai proses komunikasi, efek periklanan juga melewati beberapa tahap. Pesan periklanan akan efektif jika khalayak merasa tertarik dan mengingat konten atau pesan yang dikirimkan. Oleh karena itu pengiklan harus memahami bagaimana karakteristik penerima pesannya. Sebaliknya, jika isu-isu yang disampaikan tidak menarik perhatian penerima pesan maka digunakan pesan-pesan peripheral. Persuasi iklan akan efektif jika pesan-pesan iklan dibuat dengan terlebih dahulu memahami kondisi psikologis sasaran persuasi. Di era digital, pengiklan perlu selangkah lebih maju lebih efisien dalam melakukan aktivitas periklanan. Di era ini pengiklan tidak lagi harus memasang iklannya di media tradisional dan mengeluarkan banyak biaya dengan harapan ada calon pelanggan yang tertarik dan kemudian membeli. Kini pengiklan tidak perlu lagi membuang uangnya untuk menarik konsumen yang tidak tertarik dengan produk yang diiklankan. Hal ini merupakan esensi dari "smart advertising" yang menarget individual dan mempersonalisasi iklan sesuai kebutuhan mereka melalui internet dan ponsel pintar (AlMasri, 2019).

Tidak seperti metode advertising konvensional yang mengedepankan target terhadap penjualan, smart advertising lebih mengedepankan bagaimana return of communication investment produk. Smart advertising memmerlukan strategi dan kreativitas yang dibangun dan direncanakan dengan cermat. Pada era sekarang strategi tersebut akan lebih mudah diaplikasikan dalam platform elektronik atau online atau digital dibandingkan lewat siaran radio atau TV atau media cetak. Smart advertising bukan soal iklan yang didasarkan pada demografis media seperti gender, usia, pendapatan, atau 
geografis. Smart advertising adalah iklan yang disesuaikan dengan minat yang diindikasikan oleh perilaku konsumen yang terbaru dan berulang, dan bersifat kolektif. Misalnya, seorang konsumen akan membeli mobil dan meriset pembelian online. Dia mengunjungi web yang berkaitan dengan penjualan mobil dan membaca ulasan, daftar harga, serta konten otomatif lainnya. Dia melakukan hal ini empat kali dalam rentang waktu 30 hari di dalam jaringan situs web. Tipe perilaku ini menunjukkan bahwa dia adalah 'auto shopper,' segmen yang terdiri dari orang yang suka berkunjung dan menelisi konten. Penempatan iklan untuk sasaran ini akan menciptakan kesan hanya setelah pengguna web memenuhi kriteria ini yang menyebabkannya termasuk dalam golongan 'auto shopper.' Iklan tidak selalu harus disampaikan dalam konten otomotif tetapi dapat juga melalui ruang iklan yang tersedia.

Smart advertising memanfaatkan konsep behavioral advertising atau periklanan yang disesuaikan dengan aktivitas yang telah dilakukan oleh seorang pengguna/pelanggan. Dalam konteks online behavioral advertising, metode ini memanfaatkan aktivitas online calon pelanggan tersebut, misalnya dari data website yang ia kunjungi (Ur, dkk., 2012). Pengiklan online melacak pengguna saat mereka menjelajahi Internet, mereka membuat profil untuk setiap individu dengan tujuan untuk memungkinkan penargetan iklan berdasarkan minat masing-masing pengguna. Iklan penargetan dapat memberikan manfaat bagi pengiklan dengan membantu pengiklan menemukan pengguna yang lebih tertarik pada produk yang diiklankan. Selain itu, karena jaringan iklan dapat membebankan harga yang lebih tinggi untuk menayangkan iklan bertarget daripada iklan umum, iklan behavioral ini adalah cara untuk mendukung situs web dan produk yang sering dikunjungi oleh pengguna dan dapat mengurangi jumlah iklan yang dilihat konsumen yang tidak relevan dengan minat mereka. Masalahnya adalah metode pengiklanan ini memunculkan isu terkait privasi pengguna internet. Namun jika dilakukan dengan tepat, informasi tidak akan dikumpulkan. Iklan tidak disesuaikan dengan individu (nama, alamat, tanggal lahir) namun kepada segmen tertentu (pembeli mobil).

Penelitian sebelumnya yang dilakukan oleh (Winarni, 2015) berjudul representasi kecantikan perempuan dalam iklan menjelaskan bahwa Secara struktural iklan terdiri dari tanda-tanda (signs), sebagai sebuah kombinasi antara gambar (image) dan teks, sebuah iklan jelas menghasilkan sebuah informasi, yaitu berupa representasi pengetahuan tertentu. Iklan efektif dalam mempengaruhi persepsi orang-orang tentang sebuah produk, iklan juga merupakan salah satu bentuk komunikasi pemasaran yang mempunyai porsi paling besar dalam membentuk positioning produk. Reprsentasi wanita cantik dalam iklan banyak mendominasi iklan-iklan sebagai tontonan publik, penggunaan wanita cantik dalam iklan terlihat menjadi ide kreatif para kreator iklan.

Selanjutnya penelitian yang dilakukan oleh (Bungin, 2001) menjelaskan bahwa Iklan merupakan bagian penting dari serangkaian kegiatan mempromosikan produk yang menekankan unsur citra. Perjalanan mengubah cita menjadi citra ini adalah persoalan interaksi simbolik di mana obyek iklan dipertontonkan. Fokus perhatian terletak pada makna simbolik konsumen iklan yang ditampilkan dalam iklan itu sendiri, di mana simbol-simbol budaya dan kelas sosial menjadi bagian dominan dalam kehidupan.

Berdasarkan latar belakang tersebut, dalam tulisan ini akan dilakukan pembahasan mengenai smart advertising terutama berkaitan dengan tujuan, manfaat, serta metode melakukan smart advertising.

\section{METODE PENELITIAN}

Penelitian ini dilakukan dengan penelitian kepustakaan (library research) dengan pendekatan analisis deskriptif, yaitu mengumpulkan data, menyusun atau mengklarifikasi, dan menginterpretasinya. Metode deskriptif bertujuan pada pemecahan masalah dewasa ini dan actual, membicarakan beberapa kemungkinan untuk memecahkannya dengan cara mengumpulkan data kemudian dianalisa. Metode yang kedua adalah metode kepustakaan, yaitu dengan membaca dan mengumpulkan, kemudian mengambil buku-buku yang berhubungan dan mendukung dengan masalah penelitian ini. Teknik yang digunakan dalam penelitian ini, yaitu dengan cara menganalisis kalimatkalimat iklan, dilihat dari penggunaan interferensi. Data dalam penelitian ini 
diperoleh dari beberapa sumber yang di dalamnya terdapat interferensi.

\section{HASIL DAN PEMBAHASAN Smart Advertising}

Di era digital, pengiklan perlu selangkah lebih maju lebih efisien dalam melakukan aktivitas periklanan. Di era ini pengiklan tidak lagi harus memasang iklannya di media tradisional dan mengeluarkan banyak biaya dengan harapan ada calon pelanggan yang tertarik dan kemudian membeli. Kini pengiklan tidak perlu lagi membuang uangnya untuk menarik konsumen yang tidak tertarik dengan produk yang diiklankan. Hal ini merupakan esensi dari "smart advertising" yang menarget individual dan mempersonalisasi iklan sesuai kebutuhan mereka melalui internet dan ponsel pintar (Al-Masri, 2019).

Smart advertising merupakan bagian dari performance marketing yang muncul dari meningkatnya permintaan atas hasil yang lebih nyata di industri periklanan digital. Keuntungan besar dari performance marketing untuk pengiklan adalah jenis pemasaran ini memperluas sumber daya dan jangkauan mereka, dan pengiklan hanya perlu membayar untuk tayangan atau konversi yang dapat diverifikasi, dibandingkan iklan biasa yang dipasang kemudian diabaikan. Tetapi untuk membuat model ini berfungsi dengan baik, industri harus menemukan cara untuk secara akurat untuk melacak poin data utama sehingga pengiklan dapat mengkonfirmasi tindakan seperti klik-tayang dan konversi, dan mengidentifikasi penawaran dan penerbit yang menghasilkan hasil positif. Di sinilah strategi dan teknologi untuk melacak dan menganalisis kinerja kampanye digital lahir. Tujuan akhir dari pemasaran afiliasi adalah untuk mengarahkan pelanggan ke pengiklan sehingga afiliasi dapat memperoleh komisi atas penjualan tersebut.

Seiring dengan pesatnya perkembangan periklanan online dengan laju yang semakin meningkat, rasio klik per tayang untuk iklan online telah menurun dari 3\% menjadi jauh lebih sedikit dari 1\% (Farahat \& Bailey, 2012). Hal tersebut menunjukkan meningkatnya tingkat kompetisi bahkan untuk iklan secara online sehingga penting bagi pengiklan untuk meningkatkan efektivitas iklan mereka melalui smart advertising.
Dalam perkembangan advertising, media massa real-time memunculkan jaringan radio nasional pada 1920-an dan saat itu, ketika media massa memunculkan iklan massal, kampanye iklan menyebar luas. Seiring dengan perkembangan teknologi kini iklan online dapat ditargetkan untuk pengguna yang paling mungkin tertarik pada produk atau layanan tertentu. Pelanggan dapat memperoleh manfaat dari iklan yang ditargetkan tersebut sesuai dengan minat pribadi mereka, mengurangi iklan yang tidak relevan dan waktu yang diperlukan untuk menemukan produk (McDonald \& Cranor, 2010).

Jenis smart advertising ini, yang merupakan salah satu bentuk iklan bertarget, adalah praktik mengumpulkan data tentang aktivitas online individu untuk digunakan dalam memilih iklan mana yang akan ditampilkan. Iklan perilaku menciptakan profil untuk pengguna Internet berdasarkan berbagai jenis data dan kesimpulan yang diambil dari data tersebut. Cookie pihak ketiga adalah salah satu dari beberapa mekanisme yang digunakan untuk mengaktifkan iklan perilaku: jaringan iklan sentral dengan iklan di ribuan situs web dapat menetapkan dan membaca cookie, mencatat setiap kali pengguna tertentu mengunjungi salah satu situs di jaringan tersebut. Dengan mengkorelasikan situs mana yang dikunjungi individu, iklan diklik, kesimpulan tentang rentang usia dan jenis kelamin, dan perkiraan lokasi fisik berdasarkan alamat IP komputer, pengiklan membuat profil karakteristik dan kemungkinan minat iklan individu tersebut.

\section{Tujuan Smart Advertising}

Segala bentuk iklan memiliki keunggulan dan kelemahan, terutama pada iklan yang berlainan medianya. Misalnya iklan radio memiliki keunggulan tersendiri karena bersifat sangat mobile. Radio memiliki keunggulan yang bersifat intrusive, yaitu pendengar tidak harus bertindak aktif untuk menerima pesan yang disampaikan. Selain itu berita atau iklan yang diperdengarkan melalui radio dapat didengar di mana saja sampai batas jangkauan siaran radio tersebut. Sayangnya iklan melalui radio juga memiliki kelemahan karena media radio hanya mengandalkan perangkat audio, bukan visual sehingga iklan harus dapat dipahami dengan mudah oleh pendengar. Kelemahan lainnya yakni karena iklan melalui radio tidak 
dapat disimpan sehingga pendengar iklan akan mudah lupa dengan yang baru saja didengarnya (Royan, 2013).

Namun dengan berkembangnya konsep smart advertising, tujuan periklanan untuk menyebar sebanyak-banyaknya dengan harapan ada konsumen yang mau membeli menjadi bergeser menjadi iklan yang lebih secara khusus ditargetkan kepada konsumen yang kemungkinan tertarik dengan iklan dan produk yang diiklankan tersebut. Kini tujuan periklanan adalah untuk menempatkan merek perusahaan ke top of mind konsumen.

\section{Pencapaian Top of Mind}

Top-of-mindness dalam riset pemasaran secara umum didiskusikan dalam kesadaran nama merek atau konteks pengingatan kembali, yaitu, merek pertama yang muncul di pikiran ketika suatu konteks pengingatan muncul, misalnya "ketika memikirkan soda, yang mana merek yang pertama kali muncul di pikiran Anda? “. Fokus dari penelitian pada umumnya adalah hubungan antara top of mind dengan kinerja pasar merek atau niat beli pelanggan. Bagian dari alasan mengapa kesadaran top of mind telah menarik perhatian besar adalah karena para peneliti berasumsi bahwa merek pertama yang disebutkan pasti menempati posisi yang menguntungkan, dan mungkin unik, dalam ingatan konsumen, sehingga top of mind dihubungkan dengan sikap merek yang menguntungkan dan keterlibatan tinggi. Kesadaran merek top of mindtelah lama dipilih sebagai salah satu keunggulan merek yang paling penting.

Untuk menentukan tujuan pencapaian top of mind yang paling penting adalah bagaimana menggunakan strategi dan perencanaan yang tepat. Iklan tidak dipahami sebagai satu-satunya alat untuk memdongkrak penjualan sebuah produk dan mendapatkan keuntungan. Iklan adalah pintu masuk bagaimana sebuah produk itu menjadi top of mind khalayak. Loyalitas khalayak sangat ditentukan oleh keberhasilan iklan yang dibuat oleh pengiklan.

\section{Metode Smart Advertising}

Dalam beberapa tahun terakhir, konten dan layanan Internet yang populer (seperti berita online, blog, e-mail, dan layanan jejaring sosial) semakin banyak didanai oleh iklan daripada melalui tagihan kepada konsumen.
Banyak penyedia konten dan layanan Internet ("penerbit") bergantung pada pendapatan iklan untuk mengembangkan dan menyajikan penawaran mereka kepada konsumen. Penerbit web berkisar dari situs web media skala besar dan portal yang menjual iklan langsung ke pengiklan potensial ke situs dengan audiens yang lebih kecil dan lebih terspesialisasi.

Salah satu strategi yang banyak digunakan untuk meningkatkan nilai iklan adalah "smart advertising" atau iklan yang dilakukan dengan penargetan perilaku. Dengan menggunakan informasi tentang perilaku online, termasuk situs yang dikunjungi dan minat pada jenis konten tertentu, penargetan perilaku berupaya untuk menayangkan iklan yang lebih menarik bagi kelompok konsumen tertentu. Jika iklan lebih cocok dengan minat konsumen, konsumen lebih cenderung merespons pesan, dan pengiklan akan bersedia membayar lebih untuk iklan yang dikirim ke audiens seperti itu.

Penargetan perilaku digunakan dalam berbagai cara. Penayang besar dengan beragam konten yang ditawarkan dapat menggunakan penargetan perilaku di berbagai situs mereka untuk menawarkan kepada pengguna lebih banyak iklan bertarget. Selain itu, perusahaan pihak ketiga dapat berspesialisasi dalam bagian-bagian dari proses ini atau dapat mencakup semuanya, menawarkan penargetan di berbagai konten penerbit. Misalnya, pertukaran data berspesialisasi dalam pengumpulan data dan analisis yang mereka jual kepada pengiklan. Jaringan iklan pihak ketiga yang lebih komprehensif ("jaringan iklan") dapat menangani pengumpulan, analisis, dan perbaikan iklan (Beales, 2010).

Inovasi dalam penguraian dan pemrosesan data browsing tingkat individu memungkinkan pengiklan untuk memberikan rekomendasi produk secara langsung kepada konsumen yang kembali ke situs web mereka. Sistem rekomendasi yang dipersonalisasi ini sering menyoroti produk-produk spesifik yang dijelajahi konsumen sebelum mereka meninggalkan situs web, dan dapat meningkatkan penjualan. Namun, konsumen yang menelusuri produk secara online sering meninggalkan situs web tanpa membeli dan tidak kembali. Perusahaan yang menawarkan layanan penargetan ulang menunjukkan peningkatan kuat dalam efektivitas iklan. 
Dilaporkan bahwa iklan yang ditargetkan ulang yang dipersonalisasi enam kali lebih efektif daripada iklan banner standar, dan empat kali lebih efektif daripada penargetan ulang yang menggunakan iklan generik (Lambrecht \& Tucker, 2013). Akibatnya, penargetan ulang yang dinamis telah menarik banyak antusiasme di kalangan praktisi periklanan online. Penargetan ulang yang dinamis ini mungkin langkah selanjutnya dalam smart advertising.

Sistem rekomendasi yang dipersonalisasi dirancang untuk menjual kepada konsumen yang cukup terlibat untuk kembali ke situs web perusahaan. Sebaliknya, penargetan ulang dinamis mencoba melibatkan orang yang belum kembali ke situs web perusahaan. Namun, pertanyaan penting bagi pengiklan dan jaringan iklan adalah kapan penargetan ulang yang dinamis efektif dalam mengubah konsumen menjadi pembelian. Dalam penelitian ditunjukkan bahwa efektivitas iklan yang ditargetkan ulang tergantung pada apakah konkret pesannya cocok dengan seberapa sempit konsumen membatasi preferensi mereka (Lambrecht \& Tucker, 2013). Konsumen mungkin awalnya hanya memiliki gagasan secara luas/umum mengenai apa yang mereka sukai. Preferensi mereka ditafsirkan pada tingkat tinggi dan mereka fokus pada tujuan tingkat yang lebih tinggi. Misalnya, mereka mungkin menginginkan 'liburan santai'. Seiring waktu, konsumen mengalihkan fokus mereka ke atribut produk tertentu dan mereka mengembangkan preferensi yang sempit. Misalnya, mereka mungkin mencari hotel dengan kolam renang besar di dekat pantai. Oleh karens itu diperkirakan bahwa konsumen yang fokus pada sasaran tingkat yang lebih tinggi merespons pesan iklan dengan lebih baik yang membahas sasaran tingkat yang lebih tinggi daripada pesan yang menampilkan produk tertentu. Karena itu, hanya konsumen dengan preferensi yang terbatas nampaknya merespons positif terhadap konten iklan yang ditargetkan ulang secara dinamis.

Teknologi informasi sekarang dapat dengan mudah memonitor klik pada iklan tertentu, dan hasil monitor ini biasanya dianggap sebagai ukuran efektivitas iklan. Sebagai akibatnya, biaya per klik kini menjadi praktik penetapan harga standar untuk iklan online. Sementara itu, teknologi juga memungkinkan pengiriman iklan yang lebih bertarget kepada konsumen, misalnya, berdasarkan kata kunci yang dimasukkan konsumen di mesin pencari atau lokasi konsumen yang disimpulkan dari alamat IP komputer. Selain itu ada juga "cookies" (file teks kecil yang diinstal di komputer oleh situs web) yang secara tradisional telah digunakan untuk melacak perilaku pengguna di Web, seperti riwayat kunjungan web pengguna. Teknologi pelacakan terkini jauh lebih canggih dan mampu menangkap data terperinci tentang tindakan pengguna dan perilaku online (Chen \& Stallaert, 2010). Smart advertising yang menargetkan perilaku ini telah digunakan untuk berbagai format iklan di Internet. Misalnya, iklan spanduk apa pun yang dikaitkan dengan laman web teks (misalnya dari dictionary.com atau MSN) dapat dipilih dengan cara untuk mencerminkan minat pengguna. Demikian pula, "pre-ro;;" (yaitu, iklan video yang muncul sebelum video yang diminta dimulai) atau "overlay ad" (yaitu, iklan yang muncul di dekat bagian bawah jendela video) dalam video online (misalnya dari YouTube atau ESPN3) juga dapat disesuaikan berdasarkan minat pengguna. Pada Juni 2011, Google mengumumkan bahwa mereka akan mengizinkan "iklan berbasis minat" (istilah Google untuk penargetan perilaku/smart advertising) untuk semua pengiklan di Jaringan Display Google (Chen \& Stallaert, 2010). Iklan berbasis minat dilelang berdasarkan tarif klik per tayang, dan minat pengguna diperoleh dari perilaku penelusuran online mereka.

\section{Permasalahan dengan Smart Advertising Privasi}

Pengiklan online melacak pengguna saat mereka menjelajahi Internet, mereka membuat profil untuk setiap individu dengan tujuan untuk memungkinkan penargetan iklan berdasarkan minat masing-masing pengguna. Iklan penargetan dapat memberikan manfaat bagi pengiklan dengan membantu pengiklan menemukan pengguna yang lebih tertarik pada produk yang diiklankan. Selain itu, karena jaringan iklan dapat membebankan harga yang lebih tinggi untuk menayangkan iklan bertarget daripada iklan umum, iklan behavioral ini adalah cara untuk mendukung situs web dan produk yang sering dikunjungi oleh pengguna dan dapat mengurangi jumlah iklan yang dilihat konsumen yang tidak relevan dengan minat mereka. Masalahnya adalah metode 
pengiklanan ini memunculkan isu terkait privasi pengguna internet. Namun jika dilakukan dengan tepat, informasi tidak akan dikumpulkan. Iklan tidak disesuaikan dengan individu (nama, alamat, tanggal lahir) namun kepada segmen tertentu (pembeli mobil).

Meskipun terdapat potensi peningkatan yang dramatis untuk pengiklan dan penerbit online, beberapa pengguna dan kelompok advokasi pengguna telah menyatakan keprihatinan atas masalah privasi yang ditimbulkan oleh penargetan perilaku(Crozier et al., 2009). Regulasi biasanya berusaha menetapkan seperangkat prinsip yang harus diperhatikan oleh penyedia layanan Internet (ISP) dan pengumpul data perilaku pengguna lainnya. Salah satu prinsip tersebut adalah bahwa pengumpul data harus menerima "persetujuan tertulis afirmatif [dari pengguna] untuk Penggunaan Data Sensitif." Beberapa penerbit online (misalnya, Google) mengharuskan pengguna untuk secara eksplisit memilih sebelum mereka mengumpulkan data sensitif, dan mereka memungkinkan pengguna untuk memilih dan menentukan informasi apa yang dapat dikumpulkan dan untuk apa informasi itu dapat digunakan.

\section{Cost vs Benefit}

Pengiklan akan siap membayar lebih banyak untuk menempatkan iklan, karena iklan tersebut lebih cenderung diklik. Hal ini pada gilirannya berarti bahwa situs web akan dapat membebankan biaya lebih banyak untuk slot iklan mereka. Namun, hubungan yang diharapkan antara pembayaran dan jumlah klik ini tidak serta merta muncul ketika slot iklan dilelang. Sebaliknya, menggunakan iklan bertarget ternyata memiliki efek yang sama dengan diferensiasi produk: menyebabkan persaingan yang santai di antara pengiklan, dan karenanya mungkin bahwa pengiklan tidak perlu membayar sebanyak untuk slot iklan seperti yang mereka lakukan di bawah iklan tradisional (Chen \& Stallaert, 2010). Dengan berfokus pada segmen pengguna tertentu, iklan pengiklan dapat dipilih dengan harga yang relatif rendah berdasarkan penargetan perilaku. Artinya, karena lebih sedikit pengiklan yang fokus pada pengguna yang ditargetkan, maka kemungkinan besar pengiklan yang berfokus pada pengguna tertentu memiliki nilai rendah dan/atau probabilitas klik-tayang rendah untuk pengguna ini, yang memungkinkan pengiklan yang menang membayar lebih sedikit untuk slot iklan. Di sisi lain, juga ada efek negatif dari persaingan santai untuk penerbit online yang mungkin diimbangi oleh efek kecenderungan positif di bawah penargetan perilaku: peningkatan kemungkinan klik-tayang yang berasal dari penargetan iklan. Efek kecenderungan menghasilkan volume kliktayang yang lebih tinggi, yang memberikan kontribusi positif bagi pendapatan penerbit. Apakah penerbit dapat mengambil manfaat/laba dari penargetan perilaku tergantung pada trade-off antara efek kompetitif dan efek kecenderungan. Penargetan perilaku mengungguli iklan tradisional hanya jika efek kompetitif didominasi oleh efek kecenderungan. Keuntungan ini di bawah penargetan perilaku meningkat dalam heterogenitas pengguna dan jumlah pengiklan, dan pendapatan yang diharapkan untuk penerbit dapat berlipat ganda dibandingkan dengan iklan tradisional.

\section{SIMPULAN}

Dengan berkembangnya konsep smart advertising tujuan periklanan untuk menyebar sebanyak-banyaknya dengan harapan ada konsumen yang mau membeli menjadi bergeser menjadi iklan yang lebih secara khusus ditargetkan kepada konsumen yang kemungkinan tertarik dengan iklan dan produk yang diiklankan tersebut. Kini tujuan periklanan adalah untuk menempatkan merek perusahaan ke top of mind konsumen. Dalam beberapa tahun terakhir, konten dan layanan Internet yang populer (seperti berita online, blog, e-mail, dan layanan jejaring sosial) semakin banyak didanai oleh iklan daripada melalui tagihan kepada konsumen. Salah satu strategi yang banyak digunakan untuk meningkatkan nilai iklan adalah "smart advertising" atau iklan yang dilakukan dengan penargetan perilaku. Dengan menggunakan informasi tentang perilaku online, termasuk situs yang dikunjungi dan minat pada jenis konten tertentu, penargetan perilaku berupaya untuk menayangkan iklan yang lebih menarik bagi kelompok konsumen tertentu. Jika iklan lebih cocok dengan minat konsumen, konsumen lebih cenderung merespons pesan, dan pengiklan akan bersedia membayar lebih untuk iklan yang dikirim ke audiens seperti itu. Pengiklan online melacak pengguna saat 
mereka menjelajahi Internet, mereka membuat profil untuk setiap individu dengan tujuan untuk memungkinkan penargetan iklan berdasarkan minat masing-masing pengguna. Masalahnya adalah metode pengiklanan ini memunculkan isu terkait privasi pengguna internet. Meskipun terdapat potensi peningkatan yang dramatis untuk pengiklan dan penerbit online, beberapa pengguna dan kelompok advokasi pengguna telah menyatakan keprihatinan atas masalah privasi yang ditimbulkan oleh penargetan perilaku.

\section{DAFTAR PUSTAKA}

Al-Masri, A. (2019). Smart Technologies and Innovation for a Sustainable Future: Proceedings of the 1st American University in the Emirates International Research Conference-Dubai, UAE 2017. Springer.

Alnahdi, S., Ali, M., \& Alkayid, K. (2014). The effectiveness of online advertising via the behavioural targeting mechanism. The Business \& Management Review, 5(1), 23.

Andrews, J. C., \& Shimp, T. A. (2017). Advertising, promotion, and other aspects of integrated marketing communications. Ontario: Nelson Education.

Beales, H. (2010). The value of behavioral targeting. Network Advertising Initiative, 1.

Chen, J., \& Stallaert, J. (2010). An economic analysis of online advertising using behavioral targeting.

Durianto, D. (2004). Brand Equity Ten Strategi Memimpin Pasar. Jakarta: Gramedia Pustaka Utama.

Farahat, A., \& Bailey, M. C. (2012, April). How effective is targeted advertising? In Proceedings of the 21st international conference on World Wide Web (pp. 111120). ACM.

Griffin, R. W., \& Ebert, R. J. (2007). Bisnis. Edisi kedelapan. Jakarta: Erlangga.

Kotler, P. (2012). Kotler on marketing. New York: Simon and Schuster.

Kotler, P., Burton, S., Deans, K., Brown, L., \& Armstrong, G. (2015). Marketing. Pearson Higher Education AU.

Lambrecht, A., \& Tucker, C. (2013). When does retargeting work? Information specificity in online advertising. Journal of Marketing Rese arch, 50(5), 561-576.

Marcella, J. (2004). Arsitektur \& perilaku manusia. Jakarta: Grasindo.

McDonald, A., \& Cranor, L. F. (2010, August). Beliefs and behaviors: Internet users' understanding of behavioral advertising. TPRC.
McStay, A. (2011). The mood of information: a critique of online behavioural advertising. A\&C Black.

Radder, L., \& Huang, W. (2008). High-involvement and low-involvement products: A comparison of brand awareness among students at a South African university. Journal of Fashion Marketing and Management: An International Journal, 12(2), 232-243.

Royan, F. M. (2013). Smart Launching New Product. Elex Media Komputindo.

Setiadi, N. J. (2015). Perilaku konsumen. Kencana.

Simamora, B. (2002). Aura merek. Jakarta: Gramedia Pustaka Utama.

Ur, B., Leon, P. G., Cranor, L. F., Shay, R., \& Wang, Y. (2012, July). Smart, useful, scary, creepy: perceptions of online behavioral advertising. In proceedings of the eighth symposium on usable privacy and security (p. 4). ACM.

VanHoose, D. D. (2011). Ecommerce economics. Routledge.

Abeza, G., O’Reilly, N., Séguin, B., \& Nzindukiyimana, O. (2017). The world's highest-paid athletes, product endorsement, and Twitter. Sport, Business and Management: An International Journal, $\quad 7(3)$, 332-355. https://doi.org/10.1108/sbm-08-20160040

Khan, J., Khusro, S., \& Jabeen, F. (2014). Digital Signage Systems:Past, Present and Future. The $3 \mathrm{Rd}$ International Conference on Computer Science \& Computational Mathematics, (May), 196-208.

Kireyev, P., Pauwels, K., \& Gupta, S. (2016). Do display ads influence search? Attribution and dynamics in online advertising. International Journal of Research in Marketing, 33(3), 475490.

https://doi.org/10.1016/j.ijresmar.2015.09. 007

Moeran, B. (2015). Advertising Agencies. International Encyclopedia of the Social \& Behavioral Sciences: Second Edition (Second Edi, Vol. 1 ). https://doi.org/10.1016/B978-0-08097086-8.95093-1

Sinclair, J. (2015). Advertising: General. International Encyclopedia of the Social \& Behavioral Sciences (Second Edition, Vol. 1). Elsevier. https://doi.org/10.1016/B978-008-097086-8.95097-9

Van Den Hooff, B. (2017). Information and Communication Technologies in Organizations. The International Encyclopedia of Organizational Communication, 15, 1-20. 